\title{
Changes in Hyaluronan Deposition during Early Respiratory Distress Syndrome in Premature Monkeys
}

\author{
SANDRA E. JUUL. MICHAEL G. KINSELLA, J. CRAIG JACKSON. WILLIAM E. TRUOG.
} THOMAS A. STANDAERT. AND W. ALAN HODSON

Departments of Pediatrics and Pathology: Lniversity of Washington. Seattle. W'ashingtom 98195 /.M.G.K.. J.C.J. W.E.T. T.4.S., W.4.H.J. and Department of Pediatrics, Lniversity of Florida. Gainesville. Florida 32606 /S.E.J.I

\begin{abstract}
Increased deposition of hyaluronan (HA) is part of the early response to fibrogenic stimulus in the lung exposed to bleomycin injury and has been associated with increased lung water in adult animals. Early respiratory distress syndrome (RDS) in premature infants is characterized by increased lung water, and late sequelae include fibrosis or bronchopulmonary dysplasia. We hypothesized that increased HA in the alveolar interstitium would be associated with increasingly severe RDS in prematurely delivered monkeys and that modes of therapy that affect severity of disease such as treatment with high-frequency oscillatory ventilation or exogenous surfactant would decrease this response. Thirty-four Macaca nemestrina monkeys were delivered at $134 \pm 1 \mathrm{~d}$ (term $=168 \mathrm{~d})$ and randomized to high-frequency oscillatory ventilation or conventional mechanical ventilation from birth. Sixteen of these animals received surfactant. At $6 \mathrm{~h}$ of age, the right lower lung was frozen in situ during inflation to $30 \mathrm{~cm}$ $\mathrm{H}_{2} \mathrm{O}$ (approximately $2940 \mathrm{~Pa}$ ) and then dehydrated and processed for microscopy. The presence and severity of RDS were evaluated by clinical and morphologic criteria. HA concentrations in lung extracts increased with progressively severe $\operatorname{RDS}(p=0.0003)$. Treatment with highfrequency oscillatory ventilation decreased the lung injury score (1.69 \pm 0.7 compared with $2.5 \pm 0.9, p=0.05)$, but changes in lung $\mathrm{HA}$ concentration did not reach significance $(37.9 \pm 22.7$ compared with $44.8 \pm 22.6)$. Surfactant treatment decreased lung $\mathrm{HA}$ concentration $(29.6 \pm 19.0$ $\mu \mathrm{g} /$ wet lung) compared with non-surfactant-treated animals $(54.7 \pm 20.2 \mu \mathrm{g} / \mathrm{g}$ wet lung, $p=0.0009)$. Two fetal animals (144 and $163 \mathrm{~d}$ gestation) and seven additional premature animals ventilated for up to $96 \mathrm{~h}$ were compared with the animals killed at $6 \mathrm{~h}$. HA concentrations increased with length of mechanical ventilation and severity of illness in these animals. HA was localized in freeze-dried lung sections using a biotinylated probe. Lung sections were blindly scored for the distribution of HA staining, and these scores were positively correlated with $\mathrm{HA}$ concentration measurements $(r=0.75, p<0.0001)$. The quantity of $\mathrm{HA}$ in alveolar microvasculature correlated with severity of RDS $(r=0.68, p=0.0004)$. We conclude that $l)$ HA concentration in RDS lungs of prematurely delivered infant monkeys is increased relative to normal lungs at $6 \mathrm{~h}, 2$ ) increased $\mathrm{HA}$ is localized predominantly to the perivascular space of lung vasculature, and 3 ) this response is
\end{abstract}

Received April 2, 1993; accepted September 15, 1993

Correspondence: Sandra E. Juul, M.D., Department of Pediatrics. Division of Neonatology, Box 100296, JHMHC, Gainesville, FL 32610.

Supported by Public Health Service Grants RR00166 (Regional Primate Research Center at the University of Washington). HL 39157. and HL 18645. decreased by surfactant treatment. (Pediatr Res 35: 238243,1994 )

Abbreviations

CMV, conventional mechanical ventilation

HA, hyaluronic acid, hyaluronan

$\mathrm{HABr}, \mathrm{HA}$ binding region

HFOV, high-frequency oscillatory ventilation

RDS, respiratory distress syndrome

$\mathrm{PaO}_{2}$, arterial partial pressure of oxygen

$\mathrm{HA}$ is a major component of the extracellular matrix surrounding migrating and proliferating cells, and so is an important component of healing or regenerating tissue. One molecule of HA may contain as many as 50000 repeating disaccharide units [glucuronic acid $\beta$ and $(1 \rightarrow 3) \mathrm{N}$-acetyl glucosamine] in a linear array. Extensive intrachain hydrogen bonding, mutual repulsion between the negatively charged carboxylate groups, and the $\beta$ linkages between the sugar residues lend $\mathrm{HA}$ an inherent stiffness $(1,2)$. The large number of hydrophilic residues on the HA chain bind water, resulting in a viscous hydrated gel. Given no constraints, a hydrated HA molecule will occupy a volume 1000 to 10000 times the space of $\mathrm{HA}$ alone. The $\mathrm{COO}^{-}$groups along the molecule also bind cations, increasing the osmotic pressure in the gel. Thus, large amounts of water are taken up in the presence of $\mathrm{HA}$, increasing the turgor pressure within the matrix. $\mathrm{HA}$ also interacts or aggregates with other large proteoglycans forming even larger complexes. In addition to its space-filling role, HA can act as a specific ligand for HA receptors. Two such receptors have been identified: CD44 (3) and RHAMM (4). The interaction of $\mathrm{HA}$ with these receptors mediates several functions during normal cellular metabolism (5), as well as during developmental $(6,7)$ and repair processes $(8)$.

In normal mature lung, $\mathrm{HA}$ is present at the basal surfaces of bronchiolar epithelium and in the adventitia of muscularized blood vessels, whereas little if any is present within the alveolar interstitium (9). Increased HA deposition has been associated with early injury in bleomycin-injured rat lungs (10), adult RDS (11), and emphysema (12), whereas increased HA synthesis has been reported in nonhuman primates with RDS (13). The large hydrodynamic volume of $\mathrm{HA}$ is thought to create a favorable environment for cell migration, an important component of early response to injury. The increase in HA seen in these disease states may promote pulmonary macrophage aggregation (14) and fibroblast migration (15) and may also contribute to alterations in lung fluid balance and pulmonary compliance (16.17). It is interesting that not all pulmonary pathology is associated 
with increased $\mathrm{HA}$, inasmuch as a decrease in lung $\mathrm{HA}$ has been reported in group B streptococcal pneumonia (18).

Because the intrinsic characteristics of $\mathrm{HA}$ could contribute to the increased lung water and decreased lung compliance seen in infants with RDS, we hypothesized that increased HA in the alveolar interstitium would be associated with increasingly severe RDS in prematurely delivered monkeys relative to normal control lungs and that modes of therapy that affect severity of disease such as treatment with HFOV or exogenous surfactant would decrease this response. Lung development in the primate Macaca nemestrina is analogous to human lung development (19) and as such this species has been used as an experimental model for the study of lung development $(20,21)$ and the pathogenesis of RDS (22). Increased synthesis of $\mathrm{HA}$ has been reported in animals with RDS (13), but it is not known whether increased HA deposition occurs in this disease or, if so, where this excess $\mathrm{HA}$ is localized. The early response to injury by this damaged tissue is critical to the subsequent healing and maturation of the lung.

\section{MATERIALS AND METHODS}

In vivo methods. Eighteen Macaca nemestrina monkeys were studied as a part of a related experiment comparing the effects of CMV and HFOV on the development of alveolar edema in monkeys at risk for $\operatorname{RDS}$ ( $n=9$ in each group) (22). An additional 16 surfactant-treated animals formed part of a second protocol extending the studies of mechanical ventilation and were included in this analysis ( $n=8$ randomized to HFOV and $n=8$ randomized to $C M V$ ). Seven additional animals were delivered at $134 \pm 1 \mathrm{~d}$ gestation and were mechanically ventilated (CMV) for varying lengths of time up to $96 \mathrm{~h}$. Two fetal animals (aged 144 and $162 \mathrm{~d}$ ) were also included for comparison.

Animals were delivered by hysterotomy at $134 \pm 1 \mathrm{~d}$ after timed conception; term gestation in this species is $168 \mathrm{~d}$. The infants were quickly dried, weighed, and positioned under a radiant warmer. A cuffed endotracheal tube $(2.0 \mathrm{~mm}$ inner diameter) was immediately inserted and then connected to the assigned mechanical ventilator. Bovine surfactant supplied by Ross Laboratories (Division of Abbot Laboratories, N. Chicago, IL), as a liquid formulation of Survanta (beractant) intratracheal suspension $(4 \mathrm{~mL} / \mathrm{kg})$ was given over the first several minutes of life to 16 of the 34 animals studied at $6 \mathrm{~h}$. In HFOV animals, the mean airway pressure was kept at $15 \mathrm{~cm} \mathrm{H}_{2} \mathrm{O}(1470 \mathrm{~Pa})$, and amplitude was adjusted to maintain a $\mathrm{PCO}_{2}$ between 35 and 45 torr $(4.7-6.0 \mathrm{kPa})$. In $\mathrm{CMV}$ animals, the mean airway pressure was raised from $8 \mathrm{~cm} \mathrm{H}_{2} \mathrm{O}(784 \mathrm{~Pa})$ to $13 \mathrm{~cm} \mathrm{H} \mathrm{H}_{2} \mathrm{O}(1274 \mathrm{~Pa})$ at $6 \mathrm{~h}$ to prevent hypoxia. One hundred percent oxygen was provided throughout the duration of the study for all 6-h animals. An umbilical artery catheter was placed in the lower abdominal aorta for administration of fluids and medication. A rectal temperature probe was inserted and a radiant heat source was servocontrolled to a skin thermistor to keep the rectal temperature between $36.5^{\circ}$ and $37.5^{\circ} \mathrm{C}$. Arterial blood gas tensions were measured at least hourly by the withdrawal of samples from the umbilical artery catheter (Corning 168, Corning Medical, Medfield, MA); all blood losses were replaced with maternal whole blood. Morphine sulfate at $24 \mu \mathrm{g} / \mathrm{kg} / \mathrm{h}$ was administered for sedation through the umbilical artery catheter with dextrose $10 \%$ in water at a rate of $150 \mathrm{~mL} / \mathrm{kg} / \mathrm{d}$. Blood pressure and heart rate were monitored continuously and recorded hourly. To maintain muscular paralysis, pancuronium bromide, $0.1 \mathrm{mg} / \mathrm{kg}$, was given every $2 \mathrm{~h}$. Anteroposterior and lateral chest radiographs were obtained in all animals at 2 and $5 \mathrm{~h}$ of age and graded by three blinded observers for presence and severity of RDS ( $1=$ normal, $2=$ mild, $3=$ severe RDS). The two chest radiograph scores were added to give a possible range from 2 to 6 . The presence and severity of clinical RDS were assessed by the following criteria: serial $\mathrm{PaO}_{2}\left[1=\right.$ the majority of values of $\mathrm{PaO}_{2} \geq 400$ torr $(53.3 \mathrm{kPa}), 2=\mathrm{PaO}_{2}$ of $300-399$ torr $(40-53.2 \mathrm{kPa}), 3=$
$\mathrm{PaO}_{2}$ of 200-299 torr (26.6-39.9 kPa). $4=\mathrm{PaO}_{2}$ of $100-199$ torr $(13.3-26.5 \mathrm{kPa})$, and $5=\mathrm{PaO}_{2} \leq 100$ torr $\left.(13.3 \mathrm{kPa})\right]$. chest radiograph score, and the gross appearance of lungs at the time of thoracotomy $(1=$ pale pink, well-inflated, normal appearing lungs: 2 = patchy arcas of atelectasis, dark pink areas: $3=$ dark pink lungs, large areas of atelectasis and/or hemorrhage, lungs sink in water). The presence and severity of RDS was graded () to $3+$ on the basis of the cumulative score $(0=$ no RDS, range 4-6 cumulative points; $1+=$ mild RDS, range $7-9 ; 2+=$ moderate $R D S$, range $10-12$; and $3+=$ severe $R D S$, range $13-$ 14). Ventilated, oxygenated animals with a score of 0 were used as controls $(n=8)$.

In the animals that were ventilated for longer than $6 \mathrm{~h}$, ventilator settings and inspired oxygen were altered as needed to keep the $\mathrm{PaO}_{2}$ between 50 and 100 torr $(6.7-13.3 \mathrm{kPa})$ and the arterial $\mathrm{PCO}_{2}$ between 35 and 45 torr $(4.7-6 \mathrm{kPa})$. All these animals were ventilated with CMV.

Frozen tissue samples. At $6 \mathrm{~h}$ of life, monkeys were anesthetized with $30 \mathrm{mg} / \mathrm{kg}$ sodium pentobarbital i.v. A right intercostal incision was made. The exposed lung was sighed twice to $30 \mathrm{~cm}$ $\mathrm{H}_{2} \mathrm{O}$ pressure $(2940 \mathrm{~Pa})$ and quickly frozen with Freon 22 (DuPont, Wilmington, DE) at $-150^{\circ} \mathrm{C}$. Samples of the frozen right lower lobe were removed with a small rotary saw while freezing continued. Samples were then dried for $2 \mathrm{~d}$ at 0.001 torr at $-50^{\circ} \mathrm{C}$ and fixed with paraformaldehyde vapor (22). One sample from each animal was infiltrated and embedded with melted paraffin.

Radiometric assay: A radiometric assay was used to quantitate HA per $g$ wet lung on at least one block of tissue obtained from the right lower lobe and as many as three blocks from the right upper and lower lobes of lung from 33 animals (tissue from one monkey was not available for assay). Lung tissue was consistently taken from peripheral parenchyma for assay purposes. Approximately $50 \mathrm{mg}$ of lung were homogenized in $500 \mu \mathrm{L}$ of $0.1 \mathrm{M}$ Tris buffer and subjected to overnight Pronase (Sigma. St. Louis. MO) digestion ( $25 \mu \mathrm{g}$ per $500 \mu \mathrm{L}$ sample) at $45^{\circ} \mathrm{C}$. The Pronase was inactivated by boiling for $2 \mathrm{~min}$ after digestion. Samples were centrifuged for $2 \mathrm{~min}$ at $14000 \mathrm{rpm}$ and the resulting supernatant was removed, weighed, and diluted 1:50. Duplicate aliquots were assayed for $\mathrm{HA}$ using a technique (Pharmacia Diagnostics. Uppsala. Sweden) based on the use of the specific binding region ( $\mathrm{HABr}$ ) from bovine nasal cartilage chondroitin sulfate proteoglycan core protein. HA from the sample $(100 \mu \mathrm{L})$ was allowed to bind ${ }^{125} \mathrm{I}$-labeled $\mathrm{HABr}$ in solution for at least 60 min. The unbound ${ }^{125}$ l-labeled $\mathrm{HABr}$ was then quantified after interaction with HA covalently bound to AH Sepharose beads. Duplicate assays from at least one block of lung from all monkeys were done together with a standard curve. The standard curve was done in triplicate. Variability was less than $2 \%$. This entire series of assays was duplicated with a standard curve. In addition. when available, up to three blocks of lung tissue were independently assayed for each experimental animal. All results from each animal were averaged. The entire series of samples was run in each independent determination.

DNA assay: Lung tissue DNA was assayed by a fluorometric procedure using Hoechst dye 33258 (Sigma) essentially as described by Labarca and Paigen (23). Briefly, $8-25 \mathrm{mg}$ of frozen lung per sample were minced and sonicated at $60^{\circ} \mathrm{C}$ in $1 \%$ SDS in assay buffer composed of $0.05 \mathrm{M} \mathrm{NaPO}_{4}$ buffer, pH 7.4. containing $2 \mathrm{M} \mathrm{NaCl}$ and $2 \mathrm{mM}$ EDTA (to inhibit DNAse activity). Tissue homogenates were diluted 10 -fold in the same buffer without SDS, and $1-\mu \mathrm{L}$ triplicate aliquots were diluted into $1 \mathrm{~mL}$ of assay buffer containing 33258 Hoechst dye $(1.5 \times$ $\left.10^{-6} \mathrm{M}\right)$. Increased fluorescence was determined with a spectrophotofluorometer with excitation wavelength at $360 \mathrm{~nm}$ and emission recorded at $450 \mathrm{~nm}$ and compared with standard curve constructed using calf thymus DNA.

Localization of HA in tissue sections. Freeze-dried lung sections from 23 animals were available for study and were prepared for staining by hydration in PBS and incubation for $10 \mathrm{~min}$ each 
of the following: $70 \%$ alcohol, methanol containing $0.3 \%$ hydrogen peroxide, $70 \%$ alcohol, and PBS. Biotinylated $\mathrm{HABr}$ of cartilage Aggrecan was prepared and kindly provided by Dr. Charles Underhill (Georgetown University, Washington, DC) for use as a histochemical probe for HA (9). Lung sections were incubated overnight at room temperature with a biotinylated probe $(4 \mathrm{ng} / \mathrm{L})$ for HA contained in $10 \%$ calf serum. The probe was localized after exposure to streptavidin-conjugated peroxidase using 3-amino 9-ethyl carbazole (Sigma) as substrate (red reaction product). Sections were counterstained with Mayer's hematoxylin for $5 \mathrm{~min}$. Lung sections were examined by light microscopy at 100 to $400 \times$ and scored by two blinded observers using a scale from 1 (no $\mathrm{HA}$ in the alveolar walls or in the perivascular sheaths of medium- and small-sized vessels) to 4 (large amounts of HA in alveolar walls and surrounding medium and small pulmonary vessels). Selected lung samples prefixed with $1 \%$ cetylpyridinium chloride (Sigma). $3 \%$ paraformaldehyde, and $60 \mathrm{mM}$ sucrose in PBS were compared with samples that were not prefixed. Prefixation of tissue with $1 \%$ cetylpyridinium chloride interfered with staining. To control for the presence of endogenous peroxidase, sections were incubated with $10 \%$ calf serum in PBS alone (no biotinylated $\mathrm{HABr}$ ). Control sections were also pretreated with Streptomyces hyaluronidase (Sigma) $(20 \mathrm{U} / \mathrm{mL}, 0.2 \mathrm{M}$ sodium acetate buffer, pH 5.5, for 1 $h$ at $37^{\circ} \mathrm{C}$ ) or incubated with probe that had been preadsorbed with $\mathrm{HA}\left(100 \mathrm{ng} / \mathrm{L}\right.$ overnight at $\left.4^{\circ} \mathrm{C}\right)$ to insure specificity of the reaction. Each batch of slides was run with three negative control slides. The effect of surfactant on $\mathrm{HABr}$ is not known; however. control experiments done on sections from surfactant-treated animals were not different from those experiments done without surfactant. The HABr-HA interaction is highly specific and of high affinity, occurring even in the presence of $0.9 \mathrm{M}$ guanidine hydrochloride.

Statistical methods. A two-tailed $t$ test was done to compare HA lung concentration in animals with no RDS with that in those with any severity of RDS. Tukey`s procedure for multiple comparisons was used with one-way analysis of variance to determine whether there was a difference in $\mathrm{HA}$ concentrations between RDS severity groups ( 0 to $3+$ ). Two-tailed $t$ tests were done on HA concentration from lung extracts of animals ventilated with HFOV and CMV and on lung extracts from surfactanttreated and nontreated animals. Spearman rank correlation test was done to determine whether a correlation between HA concentration from lung extracts and $\mathrm{HA}$ histologic scores $(1+$ to $4+$ ) or between HA histologic score and RDS score existed. Data are presented as the mean $\pm \mathrm{SD}$. A $p$ value of less than 0.05 was considered significant.

\section{RESUI.TS}

All animals evaluated at $6 \mathrm{~h}$ of life were treated with mechanical ventilation and $100 \%$ oxygen from birth until death. Twentysix of 34 animals had evidence of RDS. Fifteen animals had mild $(1+)$ RDS, nine animals had moderate $(2+)$ RDS, and two had severe $(3+)$ disease. Eight animals had no evidence of lung disease and served as controls. Of these eight controls, seven were ventilated with HFOV (six were surfactant treated, one was not) and one was conventionally ventilated (with surfactant treatment). The mean concentration of $\mathrm{HA}$ in lung extracts was significantly greater in all RDS animals $(50.0 \pm 21.0 \mu \mathrm{g} / \mathrm{g}$ wet lung. $n=25)$ than in animals without RDS $(19.6 \pm 11.3 \mu \mathrm{g} / \mathrm{g}$ wet lung, $n=8$ ), $p<0.001$ (Table 1).

As the severity of RDS increased, the quantity of HA in lung extracts increased $(p=0.0003)$, ranging from a mean of $19.6 \pm$ $11.2 \mu \mathrm{g} / \mathrm{g}$ wet lung in the group without RDS to $86.3 \pm 0.9 \mu \mathrm{g} /$ $\mathrm{g}$ wet lung in the most severe (3+) RDS group (Fig. 1). Tukey's procedure for multiple comparisons used with one-way analysis of variance showed the group with no RDS to be different from the mild $(1+)$, moderate $(2+)$, and severe $(3+)$ RDS animals $(p)$ $<0.05$ for each comparison). When $\mu \mathrm{g} \mathrm{HA}$ per $\mu \mathrm{g}$ DNA were determined for each group $(13600 \pm 4550,26100 \pm 4780$, and $32300 \pm 6780$ for $1+, 2+$, and $3+$ RDS, respectively), the same relationship held true $(p<0.05)$.

When all animals ventilated by $\operatorname{HFOV}(n=17)$ were compared with those ventilated by CMV $(n=16)$, no difference in HA was noted $(37.9 \pm 22.7$ and $44.8 \pm 22.6 \mu \mathrm{g} / \mathrm{g}$ wet lung. respectively) despite somewhat lower scores for severity of RDS in the HFOV group $(1.69 \pm 0.7$ and $2.5 \pm 0.9: p<0.05)$. Irrespective of mode of ventilation. HA concentration in lung extracts was lower in surfactant-treated animals $(n=16)$ compared with untreated animals $(n=17)(29.6 \pm 19$ and $54.7 \pm 20.2 \mu \mathrm{g} / \mathrm{g}$ wet lung. respectively: $p=0.0009$ ). The effect of surfactant treatment on severity of RDS and on concentration of $\mathrm{HA}$ is seen in Figure 1. with mean severity score for the surfactant-treated animals equal to $1.63 \pm 0.72$ and the RDS score for untreated animals equal to $2.56 \pm 0.82(p<0.05)$. The lowest concentration of $\mathrm{HA}$ in lung extracts was noted in the surfactant-treated lungs without RDS. regardless of mode of ventilation (Table 1).

Quantitation of HA extracted from the lungs of prematurely delivered animals maintained with prolonged CMV (up to $96 \mathrm{~h}$ ) and supplemental oxygen revealed $\mathrm{HA}$ content that varied with severity of RDS and length of mechanical ventilation. Table 2 shows the relationship of severity of illness and length of mechanical ventilation to quantity of HA. Thus, in general, the sicker the animal and the longer it was mechanically ventilated. the higher the HA content. The two fetal animals were included for comparison.

Histochemical staining of lung sections was done to determine the location of $\mathrm{HA}$ in control and RDS animals. Histologic scores ( 1 through 4 ) were given for HA staining by two blinded observers, with staining for $\mathrm{HA}$ in progressively smaller vessels and in the alveolar walls receiving higher histochemical scores. Histologic HA scores and HA quantity determined from lung extracts were correlated $(r=0.75, p<0.00001)$. There was a positive correlation between the clinically determined RDS score and the histologic HA score $(r=0.68, p<0.0004)$.

$\mathrm{HA}$ was localized to the adventitia of large muscularized blood vessels in normal and RDS lung sections with no differences noted as a result of RDS (data not shown). Similarly, the basal surfaces of bronchiolar epithelium and the surrounding cartilage were positively stained for HA. The perivascular sheaths of smalland medium-sized muscular arteries became thickened and were stained heavily for $\mathrm{HA}$ as severity of lung disease progressed (Fig. $2 B-D)$. As the severity of RDS increased. HA was increasingly associated with the microvasculature in the interalveolar spaces as determined by histologic scoring of HA. In the most severely affected cases. HA was present in the alveolar walls (Fig. 3B-D). Increased accumulations of $\mathrm{HA}$ were also noted in the interlobar and subpleural regions of lung (Fig. $3 \mathrm{D}$ )), possibly corresponding to lymphatic drainage. It should be noted that all lungs were inflated to $30 \mathrm{~cm} \mathrm{H} O(2940 \mathrm{~Pa})$ before fixation: thus, the difference in alveolar inflation reflects the disease process in these animals. Consistent with the somewhat patchy distribution of RDS, there was some heterogeneity of staining for HA within lung sections. No staining for HA was noted in hyaline membranes or proteinaceous debris present in the alveolar space of affected animals. None of the lung sections that were stained to insure specificity of the reaction showed any positive reaction product (Fig. 4.1-C). The control sections incubated with serum in PBS alone demonstrate that the red reaction product is not the result of endogenous peroxidases (Fig. 4.1). Pretreatment with Streptomice's hyaluronidase eliminated the red reaction product, demonstrating specificity of the probe (Fig. $4 B$ ). and incubation of sections with probe that had been preadsorbed with $\mathrm{HA}$ also eliminated the red reaction product. demonstrating specificity of the HABr-HA interaction (Fig. 4(').

\section{DISCUSSION}

The quantity of $\mathrm{HA}$ in lungs of premature primates demonstrated to have RDS at $6 \mathrm{~h}$ of life is greater than that found in 


\begin{tabular}{|c|c|c|c|c|c|}
\hline & CMV & $\begin{array}{l}\text { 1. Slx-h expe } \\
\text { CMV-SURF }\end{array}$ & $\begin{array}{c}\text { al gromps } \\
\text { HFOV }\end{array}$ & HFOV-SURF & Total \\
\hline \multicolumn{6}{|l|}{ RDS } \\
\hline$n$ & 8 & 7 & 8 & 2 & $25+$ \\
\hline $\mathrm{HA}(\mu \mathrm{g} / \mathrm{g}$ wet lung) & $60.2 \pm 19.5$ & $32.3 \pm 12.4$ & $51.5 \pm 21.2$ & $65.1 \pm 18.6$ & $50.0 \pm 21.0$ \\
\hline \multicolumn{6}{|l|}{ Normal } \\
\hline$n$ & 0 & 1 & 1 & 6 & 8 \\
\hline $\mathrm{HA}$ ( $\mu \mathrm{g} / \mathrm{g}$ wet lung) & & 13.2 & 39 & $17.5 \pm 9.4$ & $19.6 \pm 11.3$ \\
\hline
\end{tabular}

* CMV-SURF. CMV with surfactant treatment: HFOV-SURF. HFOV with surfactant treatment. HA values are mean \pm SD.

+ Tissue from one animal was unavailable for assay.

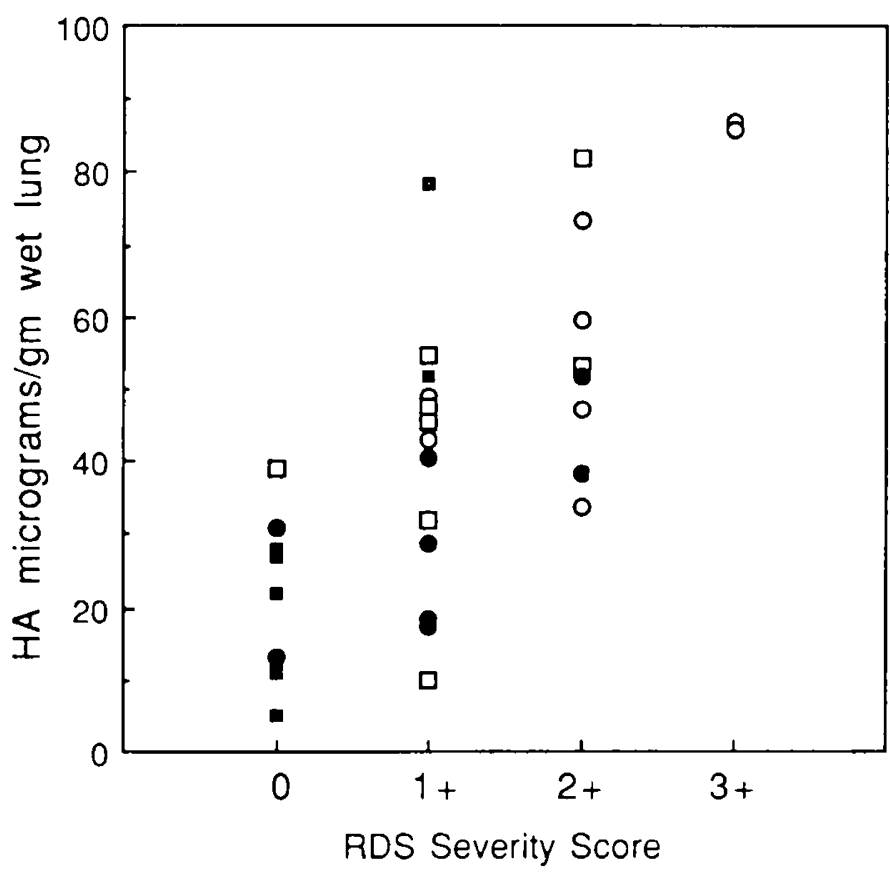

Fig. 1. Concentration of $\mathrm{HA}$ ( $\mu \mathrm{g} / \mathrm{g}$ wet lung) as determined by radioassay from lung extracts is shown as a function of severity of RDS. 0 indicates no RDS, and 3+ indicates severe RDS. Animals treated with CMV alone are shown by open circles $(n=8)$, those treated with HFOV alone are shown by open squares $(n=8)$, those treated with CMV with surfactant $(n=8)$ are shown by filled circles, and those treated with HFOV with surfactant $(n=8)$ are shown by filled squares.

Table 2. Duration of mechanical ventilation and H.A content in premature monke's

\begin{tabular}{cccc} 
& \multicolumn{3}{c}{ HA content $(\mu \mathrm{g} / \mathrm{g}$ wet lung) } \\
\cline { 2 - 4 } Ventilation $(\mathrm{h})$ & Well* & Intermediate* & \multicolumn{1}{c}{ Sick* } \\
\hline 0 & 33.4 & & \\
0 & 41.6 & & \\
1 & & 46.3 & \\
$6 \dagger$ & $19.6 \pm 11.2$ & $46.1 \pm 12.1$ & $85.6 / 86.9$ \\
18 & & & 392.4 \\
24 & & 175.7 & $274.5 / 202.2 \ddagger$ \\
30 & & & \\
64.5 & 170.9 & & 272.2 \\
96 & & & 837.0 \\
96 & & &
\end{tabular}

* Monkeys were classified as well, intermediate, or sick on the basis of clinical and pathologic criteria.

† Average values taken from 6-h animals. Individual values given when there were less than three animals.

$\ddagger$ These values were from the right and left lower lobes of one animal. The higher value was from the lung that appeared more atelectatic.
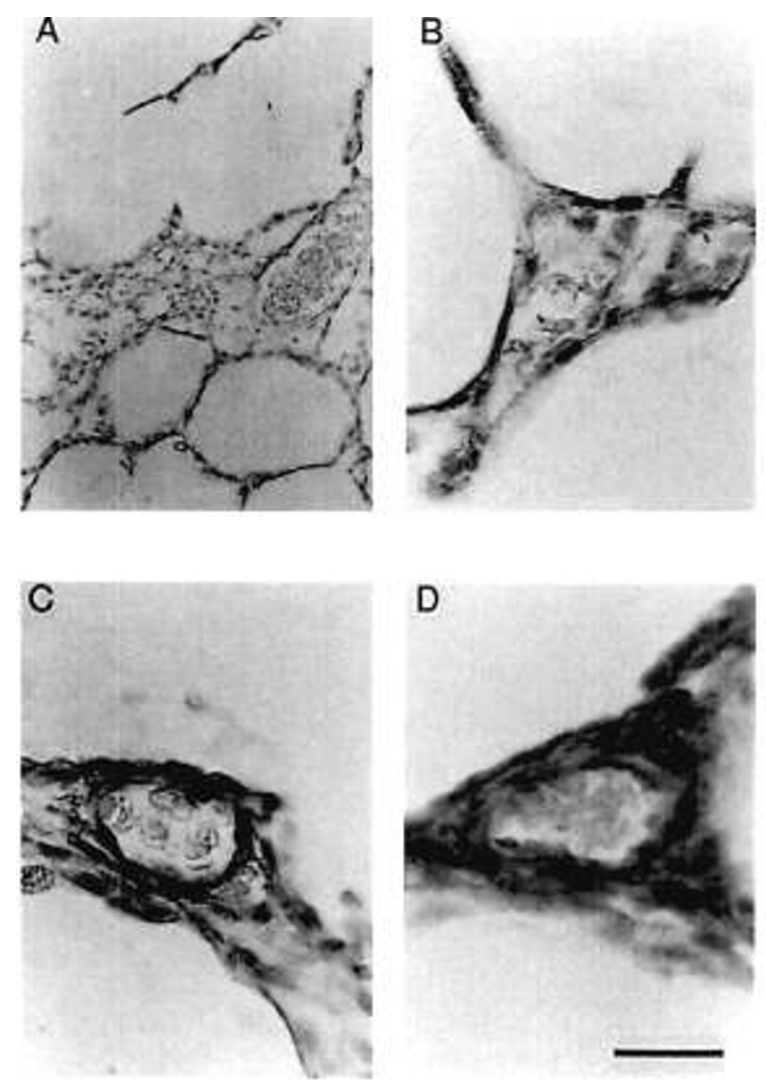

Fig. 2. Freeze-dried lung sections. stained for HA (red) using an indirect avidin-biotin-peroxidase technique to localize biotinylated HA probe. The sections were counterstained with hematoxvlin. Panel A shows the control level of staining in the absence of the biotinylated HA probe. Original magnification $100 \times$. Panels $B$ through $D$ show mediumsized muscular arteries from normal lung $(B)$ and lungs with mild RDS $(C)$ and severe RDS $(D)$. Original magnification $400 \times$. Bar $=100 \mu \mathrm{m}$ for $A$ and $30 \mu \mathrm{m}$ for $B$ through $D$.

lungs of animals without RDS, as determined by both radiometric assay and histochemical staining with a biotinylated $\mathrm{HABr}$ probe. Because all animals in this study were ventilated with supplemental oxygen from birth, this study does not address the effects of mechanical ventilation on lung HA, but rather the difference between premature ventilated animals with and without RDS. Inasmuch as data are reported in $\mu \mathrm{g} / \mathrm{g}$ wet lung. this tends to minimize the differences between the RDS and control groups, because RDS animals are known to have more lung edema and therefore heavier lungs. When lung HA per $\mu \mathrm{g}$ DNA was studied as a function of severity of RDS, the same relationship held, with increasingly severe RDS associated with increased lung HA. It is not clear from these data whether the increase in lung $\mathrm{HA}$ in early RDS reflects a relative inhibition of the normal decrease in $\mathrm{HA}$ accompanying birth, mediated through a marked increase in hyaluronidase activity (24), or an increase in HA synthesis, or both; however, previous work from our laboratory 

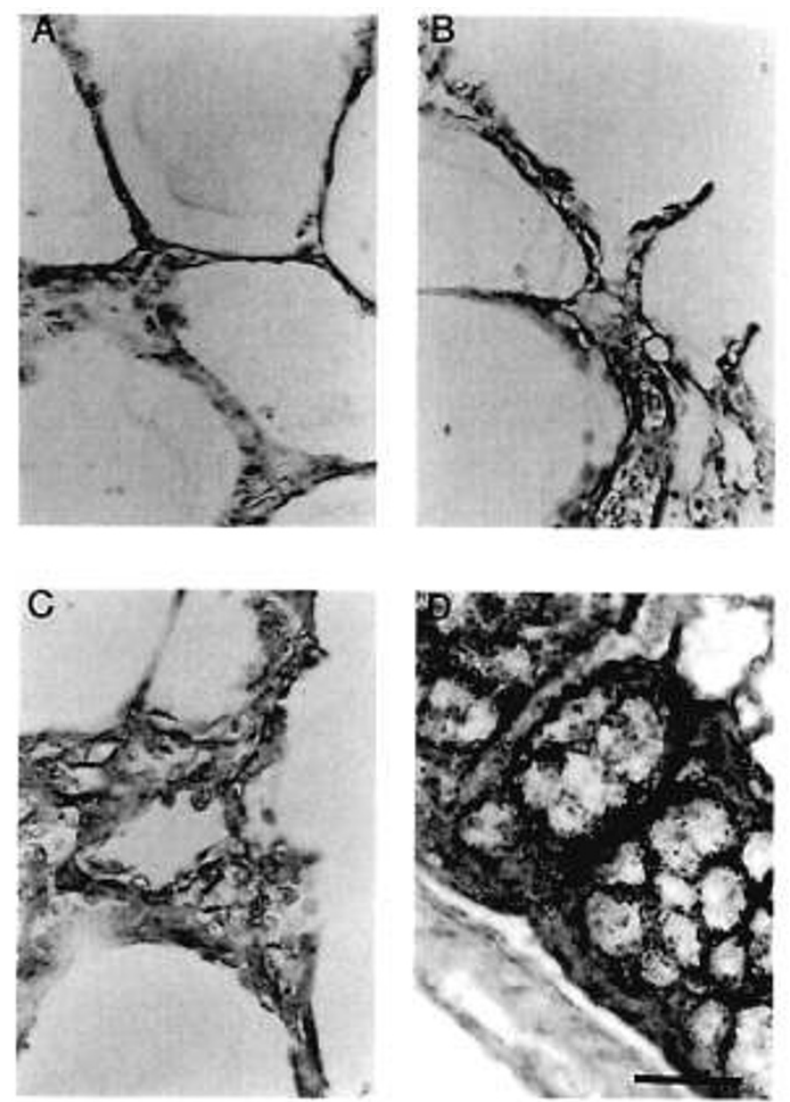

Fig. 3. Freeze-dried lung sections stained for $\mathrm{HA}$ (red) showing subpleural lung parenchyma. Panel $A$ shows the control level of staining in the absence of the biotinylated HA probe. Panel $B$ demonstrates normal lung, panel $C$ shows mild RDS, and panel $I$ ) shows severe RDS. Original magnification $100 \times$. Bar $=50 \mu \mathrm{m}$.

suggests that there is an increase in HA synthesis (13). It is likely that HA accumulation in acute RDS is just beginning at $6 \mathrm{~h}$ and that the peak excess relative to normal lungs would occur at approximately $3 \mathrm{~d}$ of life, concomitant with maximal clinical severity of disease. This is supported by data collected from three animals ventilated up to $96 \mathrm{~h}$. Although there were too few animals in this group to make statistical comparisons, clearly HA content is just beginning to rise in sick animals at $6 \mathrm{~h}$. It is remarkable, however, that by just $6 \mathrm{~h} \mathrm{HA}$ has increased as much as 3-fold in the most severely affected animals compared with the healthy animals. This highlights the dynamic nature of the extracellular matrix. This increased HA could contribute to increased lung water, decreased lung compliance, and increased pulmonary vascular resistance that occur with RDS (17). Treatment with HFOV alone, despite a decrease in severity of RDS by the scoring criteria used $(1.69 \pm 0.7$ compared with $2.5 \pm 0.9$. $p<0.05$ ), did not have a statistically significant effect on HA concentration, although mean values were decreased $(37.9 \pm$ 22.7 compared with $44.8 \pm 22.6$ ). This may be caused by inadequate sample size. Alternatively, it is possible that HA per $s e$ is not a marker of severity of lung disease. Interestingly, surfactant treatment decreased both the severity of RDS in these animals and the concentration of HA present in lung extracts, suggesting that less extensive tissue damage and cellular response have occurred. It is also possible that surfactant had a direct effect on HA metabolism independent of its effect on tissue damage.

The combination of biochemical and histochemical techniques allowed both quantification and localization of lung HA. The distribution of HA in bronchial cartilage. bronchial epithelium. and large arterial adventitia was the same in all lungs studied. whereas the distribution of HA in smaller interstitial vessels was increased in animals with RDS. In animals without RDS, minimal HA was detectable in the medium and small vessels of the lung. In animals with mild disease, the medium-sizes muscular arterioles were most affected, and as the severity of disease increased, progressively smaller pulmonary vessels accumulated perivascular HA. HA did not appear to be a component of intraalveolar hyaline membranes, suggesting that the increased HA noted in these lungs was the result of a specific cell response to injury rather than nonspecific leakage of intravascular contents into the interstitium and alveolar space.

It is not known which cells in the lung are responsible for the increase in HA accumulation during acute RDS or what the specific stimulus for increased production or decreased degradation is. It is known that exposure of lung fibroblasts in culture to transforming growth factor- $\beta$ markedly stimulates HA synthesis (25). HA synthetase induction and increased HA synthesis by human lung fibroblasts occurs after exposure of these cells to recombinant interferons, tumor necrosis factor, and lymphotoxin (26). Stretch alone may cause a change in the extracellular matrix produced by different cell types, as has been shown in pulmonary artery endothelial cells (27) and smooth muscle cells (28). Undue stretch on the immature matrix of the premature lung may be an important component of injury during acute RDS.
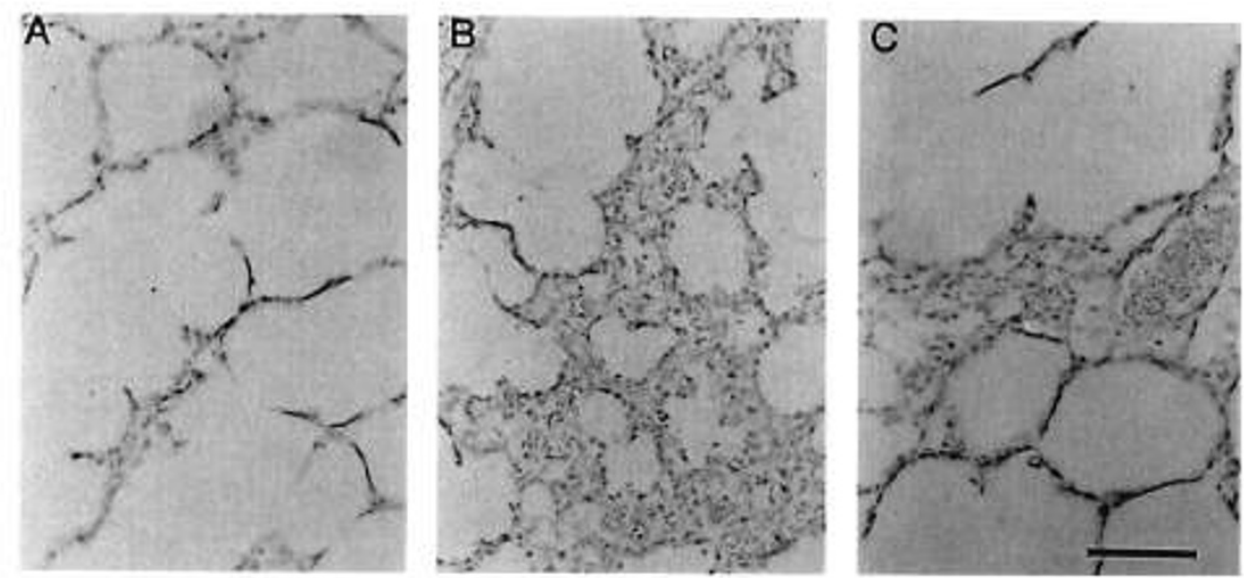

Fig. 4. Control lung sections showing specificity of red reaction product. A. Lung parenchyma from animal with moderate to severe RDS showing the control level of staining in the absence of the biotinylated HA probe. $B$. Lung parenchyma from animal with mild RDS. hyaluronidase-treated before incubation with probe (see Materials and Methods). (: Bronchial epithelium from normal lung. probe preadsorbed with HA. Original magnification $100 \times$. Bar $=100 \mu \mathrm{m}$. 
The presence of $\mathrm{HA}$ at the basal surfaces of bronchiolar epithelium, in the surrounding cartilage, and in the adventitia of large muscularized blood vessels has been shown in normal adult hamster lungs (9). We additionally found positive staining for $\mathrm{HA}$ in the perivascular region of alveolar walls in animals with RDS. Nettelbladt et al. (29) detected increased alveolar wall HA in histochemical studies of bleomycin-injured rat lung. although not in the perivascular sheath. These workers noted that the increase in HA coincided with the maximal increase in lung wet weight at $4 \mathrm{~d}$ postinjury and that some pulmonary macrophages were filled with HA (30). A complementary study in bleomycininjured rats showed the HA content in bronchoalveolar lavage to peak at $\mathrm{d} 5$, returning to baseline by 21 , with neutrophil counts following a similar course (31). This pattern of early HA accumulation in response to injury may be very important in effecting a normal healing process. During the development of acute RDS in this premature monkey model, there is a several-fold increase in neutrophils noted as early as 11 to $24 \mathrm{~h}$, continuing into the third day of disease. These cells are initially evenly distributed in the alveolar, interstitial, and vascular spaces, but with time the majority of the neutrophils are found in the interstitial space. As recovery occurs (d 4), an increase in alveolar macrophages is noted (32). The CD44 HA receptor has been demonstrated on pulmonary macrophages in significantly greater concentration than in macrophages from other tissues. Blocking this receptor using an MAb inhibits macrophage aggregation $(33,34)$. AH has also been shown to be chemotactic for neutrophils (35). It is possible that the HA secreted by injured lung cells may participate in the chemotaxis and aggregation of inflammatory cells. and that with a normal healing response, the HA is degraded by invading neutrophils and macrophages, inhibiting further influx of these cells.

The early response of the lung to injury may determine the nature and extent of the resulting dysfunction. Because changes in HA are associated with this early response to injury, experiments that manipulate the rate of synthesis or degradation should contribute new information about the pathophysiology of this early response and how it relates to normal and abnormal healing.

Acknowledgments. The authors thank Thomas N. Wight. Ph.D., for his support and guidance, and Thomas P. Strandjord. M.D., for his help with statistical analysis.

\section{REFERENCES}

1. Scott JE, Heatley F. Hull WE 1984 Secondary structure of hyaluronate in solution. AH-n.m.r. investigation at 300 ) and $500 \mathrm{MHz}$ in $\left[{ }^{2} \mathrm{H}_{0}\right]$ dimethyl sulphoxide solution. Biochem J 220:197-205

2. Heatley F, Scott JE 1988 A water molecule participates in the secondary structure of hyaluronan. Biochem J 254:489-493

3. Aruffo A, Stamenkovic I, Melnick M. Underhill CB. Seed B 1990 CD44 is the principal cell surface receptor for hyaluronate. Cell 61:1303-1313

4. Hardwick C. Hoare K. Owens R, Hohn HP. Hook M. Moore D. Cripps V. Austen L. Nance DM. Turley EA 1992 Molecular cloning of a nove hyaluronan receptor that mediates tumor cell motility. J. Cell Biol 117:13431350

5. Turley EA 1989 Hyaluronic acid stimulates protein kinase activity in intact cells and in an isolated protein complex. J Biol Chem 264:8951-8955

6. Banerjee SD. Toole BP 1991 Monoclonal antibody to chick embryo hyaluronan-binding protein: changes in distribution of binding protein during early brain development. Dev Biol 146:186-197

7. Toole BP. Munaim SI. Welles S. Knudson CB 1989 Hyaluronate-cell interactions and growth factor regulation of hyaluronate synthesis during limb development. Ciba Found Symp 143:138-145

8. Longaker MT, Harrison MR. Crombleholme TM, Langer JC, Decker M, Verrier ED. Spendlove R. Stern R 1989 Studies in fetal wound healing: I. A factor in fetal serum that stimulates deposition of hyaluronic acid. J Pediatr Surg 24:789-792
9. Green SJ. Tarone G, Underhill CB 1988 Distribution of hyaluronate and hyaluronate receptors in the adult lung. J Cell Sci 89:145-156

10. Bray BA. Sampson PM. Osman M. Giandomenico A. Turino GM 1991 Farly changes in lung tissue hyaluronan (hyaluronic acid) and hyaluronidase in bleomycin-induced alveolitis in hamsters. Am Rev Respir Dis 143:284-288

11. Hallgren R. Samuelsson T, Laurent TC. Modig J 1984 Accumulation of hyaluronan (hyaluronic acid) in the lung in adult respiratory distress syndrome. Am Rev Respir Dis 139:682-687

12. Lafuma C. Moczar M. Lange F. Robert L 1985 Biosynthesis of hyaluronic acid. heparin sulfate and structural glycoproteins in hamster lung explants during elastase-induced emphysema. Conn Tiss Res 13:169-179

13. Juul SE. Kinsella MG. Wight TN. Hodson WA 1993 Alterations in nonhuman primate (11. nemestrina) lung proteoglycans during normal development and acute hyaline membrane disease. Am J Respir (ell Mol Biol $8: 299-310$

14. Love SH. Shannon BT. Myrvik QN. Iynn WS 1977 Characterization of macrophage agglutinating factor as a hyaluronic acid-protein complex. J Reticuloendothelial Soc 25:269-284

15. Turley EA. Torrance J 1985 Localization of hyaluronate and hyaluronatehinding protein on motile and non-motile fibroblasts. Exp (ell Res 161:1728

16. Bhattacharya J. Cruz T. Bhattacharya S. Bray BA 1989 Hyaluronan affects extravascular water in lungs of unanesthetized rahbits. J Appl Physiol 66:2595-2599

17. Lai-Fook SJ, Rochester NL. Brown LV 1989 Effects of alhumin, dextran, and hyaluronidase on pulmonary interstitial conductivity. J Appl Physiol 67:6()6613

18. Juul SE. Kinsella MG, Truog WE, Redding (jJ 1992 I ung hỵaluronan decreases during experimental group B streptococcus (GBS) pneumonia in neonatal piglets. Pediatr Res 31:311 A (abstr 1851)

19. Boyden EA 1976 The development of the lung in the pig-tail monkev (1/acaca nemestrina). Anat Rec 186:15-38

20. Hodson WA, Palmer S, Blakely GA. Murphy JH. Woodrum DE, Morgan TE 1977 Lung development in the fetal primate Macaca nemestrima. I. Growth and compositional changes. Pediatr Res 11:1009-1014

21. Jackson JC, Clark JG, Standaert TA. Truog WF Murphy JH, Juul SF Chi EY. Hodson WA 1990 Collagen synthesis during lung development and during hyaline membrane disease in the non-human primate. Am Rev Respir Dis 141:846-853

22. Jackson JC Truog WE Standaen TA Juul SE Murphy Jll Chi f: MasKenzie AP. Hodson WA 1991 Effect of high frequency ventilation on the development of alveolar edema in premature monkeys at risk for hyaline membrane disease. Am Rev Respir Dis 143:865-871

23. Labarca C. Paigen K $1980 \mathrm{~A}$ simple, rapid, and sensitive DNA assay procedure. Anal Biochem 102:344-352

24. Thet LA, Howell AC, Han 1983 Changes in lung hyaluronidase activity associated with lung growth, injury and repair. Biochem Biophys Res Com mun 117:7!-77

25. Westergren TG. Sarnstrand B. Fransson LA. Malmstrom A 1990) TGiF-beta enhances the production of hyaluronan in human lung but not in skin fibroblasts. Exp Cell Res 186:192-195

26. Elias JA, Krol RC, Freundlich B, Sampson PM 1988 Regulation of human lung fibroblast glycosaminoglycan production by recombinant interferons. tumor necrosis factor, and lymphotoxin. J Clin Invest 81:325-333

27. Gorfien SF. Howard PS. Myers JC. Macarak E 1990 Cyclic biaxial strain of pulmonary artery endothelial cells causes an increase in cell layer-associated fibronectin. Am J Respir Cell Mol Biol 3:421-429

28. Leung DYM. Glagov S. Mathew's MB 1976 Cyclic stretching stimulates sin thesis of matrix components by anterial smooth muscle cells in vitro. Science 191:475-477

29. Nettelbladt O. Schenholm M. Tengblad A. Hallgren R 1989 Accumulation of hyaluronic acid in alveolar interstitial tissue in bleomycin-induced alveolitis. Am Rev Respir Dis 139:759-762

30. Nettelbladt O. Tengblad A. Hallogren R 1989 Lung accumulation of hyaluronan parallels pulmonary edema in experimental alveolitis. Am $J$ Physiol 257:L.379-L.384

31. Nettelbladt O, Hallgren R 1989 Hyaluronan (hvaluronic acid) in bronchoalveolar lavage fluid during the development of bleomvcin-induced alveolitis in the rat. Am Rev Respir Dis 140:1028-1032

32. Jackson JC. Chi EY. Wilson CB. Truog WE. Teh EC. Hodson WA 1987 Sequence of inflammatory cell migration into the lung during recovery from hyaline membrane disease in premature newhorn monkevs. Am Rev Respir Dis 1.35:9.37-940

33. Culty M. Nguyen HA. Underhill CB 1992 The hyaluronan receptor (CD44) participates in the uptake and degradation of hyaluronan. J Cell Biol 116:1055-1062

34. Green SJ. Tarone G, Underhill CB 1988 Aggregation of macrophages and fibroblasts is inhibited by a monoclonal antibody to the hyaluronate receptor. Exp Cell Res 178:224-232

35. Hakansson L., Venge $P 1987$ The molecular hasis of the hyaluronic acidmediated stimulation of granulocyte function. J Immunol 138:4.347-4352 